\title{
The Role of Ijtihad and the Development of Sharia Financial Technology Products in Indonesia
}

\author{
Ibnu Elmi A.S. Pelu ${ }^{1}$, Ahmad Dakhoir ${ }^{2}$ \\ ibnu_borneo@yahoo.com ${ }^{1}$, ahmad.dakhoir@iain-palangkaraya.ac.id ${ }^{2}$ \\ Faculty of Shariah IAIN of Palangka Raya, Indonesia ${ }^{1}$ \\ Faculty of Economics and Islamic Business IAIN of Palangka Raya, Indonesia ${ }^{2}$
}

\begin{abstract}
This paper explores the role and significance of 'ijtihad' in the development of Islamic financial technology products in Indonesia. The research methods used philosophical and conceptual approaches. Based on the analysis, this paper concludes that Islamic finance technology has a positive role in encouraging the growth of assets of Islamic financial institutions and Islamic banking. The trend of the development of Islamic financial products has turned out to be linear with the growth of the spirit of "ijtihad" through the 120 DSN-MUI fatwas, including the issuance of fatwas that regulate of financial technology. According to epistemological level, the issuance of the financial technology fatwa shows that "ijtihad" DSN-MUI is in accordance with the spirit of progressive law,that the fatwa serves as the legitimacy of fiqh in the development of contemporary financial products in Islamic banking.
\end{abstract}

Keywords: Ijtihad, Product Development, Islamic Financial Technology, Islamic Banking

\section{Pendahuluan}

Situasi perekonomian ASEAN, sedang menghadapi masyarakat ekonomi perbankan 2020 [1][2]. Lembaga keuangan termasuk perbankan syariah di Indonesia dituntut lebih inovatif dalam pengembangan produk-produknya [3]. Saat ini perbankan syariah masih memiliki ketergantungan yang tinggi terhadap produk-produk pembiayaan berbasis pada pendapatan tetap (fixed). Karakter tersebut seyogyanya dapat diperbaiki untuk mengantisipasi terjadinya volatilitas yang cepat di sisi biaya dana. Untuk menyelaraskan situasi tersebut, Indonesia perlu semangat dan produktif untuk mengembangkan skim perbankan syariah, karena perkembangan produk perbankan masih minus dan tertinggal dengan negara muslim mapun negara non-muslim lain. Produk-produk perbankan syariah di Indonesia masih monoton,terkesan kaku, dan kurang dinamis. Menurut Baljeet Kaur Grewal [4], Indonesia menempati level ketiga dalam pengembangan pasar serta produk-produk bank syariah. Adapun negara-negara pada level keempat merupakan kelompok negara-negara yang memiliki perkembangan dan segmentasi pasar keuangan syariah terbaik yaitu negara Malaysia, Uni Emirat Arab, dan Bahrain. Adapun negara-negara seperti Indonesia, Brunei Darussalam dan Afrika Utara, Turkey dan Qatar terletak pada posisi yang masih rendah dibawah Malaysia, Uni Emirat Arab dan Bahrain. Menurut Baljeet, negara-negara yang memiliki perkembangan disektor keuangan syariah memiliki 4 level.[5] Level yang paling tinggi seperti Malaysia, Kuwait, Bahrain dan Uni Emirat Arab. Adapun negara-negara yang mengembangkan bisnis di sektor keuangan syariah pada level ke 3 yaitu Indonesia, Brunei, Afrika Utara, Turki, dan Qatar. Sedangkan untuk negara dengan segmentasi dan perkembangan pasar keuangan dan perbankan syariah ke 2 yaitu 
Amerika Serikat, Syiria, Jerman, dan Lebanon. Adapun level yang pengembangan disektor keuangan dan perbankan syariah yang paling bawah adalah China, India, Hongkong dan Azerbeijan [6].

Menurut berbagai kajian, ada beberapa faktor yang menyebabkan sulitnya ekspansi pasar perbankan syariah. Faktor-faktor tersebut adalah faktor inovasi dan diversifikasi produk dan strategi [7], faktor fleksibilitas, faktor aksesibilitas[8], faktor margin [9], faktor SDM dalam mengembangkan ekonomi syariah dan faktor stabilitas keuangan [10]. Selain disebabkan faktor produk dan sumber daya manusia, lambatnya perkembangan perbankan syariah ternyata juga disebabkan lambatnya filter legislasi dan regulasi halal ekonomi dan keuangan. Faktor inovasi produk dalam mengembangkan produk keuangan syariah menjadi kunci eksistensi perbankan syariah dalam bersaing dengan perbankan konvensional. Inovasi produk akan dapat memberikan ruang gerak pengembangan produk lebih variatif. Variasi produk menjadi jalan terbaik untuk mengurangi risiko semakin berkurangnya pendapatan yang dihasilkan dari suatu produk tertentu. Sebagai contoh dalam produk pembiayaan murabahah, dapat dikombinasikan dengan produk-produk yang memungkinkan bank syariah melakukan repricing ketika terjadi perubahan biaya dana (cost of fund). Salah satunya seperti dengan mengkombinasikan dengan pembiayaan melalui akad ijarah. Hal ini mengingat, akad ijarah memberikan fleksibilitas bagi bank syariah dalam melakukan repricing atas pendapatan sewa yang dikenakan kepada nasabah dengan mengikuti pola naik dan turunnya biaya dana. Inovasi tidak cukup dalam pengembangan produk aqad yang bersifat kombinatif, tapi juga dapat dikembangkan dari regulasi yang mendukung produk baru tersebut. Pada ranah inilah, regulasi fatwa diperlukan untuk mendukung produk perbankan syariah. Sebagai contoh adalah pentingnya norma atau fatwa dalam mendukung program restrukturisasi aqad bagi nasabah yang tidak mampu melaksanakan kewajibannya. Selain itu, fatwa juga menjadi kunci utama bagi kelangsungan perbankan syariah untuk dapat bersaing dengan perbankan konvensional. Pentingnya fatwa bagi pengembangan produk perbankan syariah tidak dapat dihindari karena fatwa menjadi legitimasi dan kepastian hukum halal produk.

Kehadiran fatwa sebagai manivestasi semangat ijtihad dalam mengawal perkembangan produk perbankan syariah, merupakan implementasi prinsip demokrasi islam yang sangat relevan untuk ditelaah ulang ditengah meningkatnya kesadaran global terhadap sistem ekonomi syariah di Indonesia [11]. Kondisi ini terlihat jelas ketika negara-negara maju telah mengembangkan perbankan syariah. Berdasarkan kajian tersebut, tujuan paper ini adalah untuk mengetahui perkembangan produk perbankan syariah. Paper ini juga akan menganalisis bagaimana signifikansi ijtihad khususnya fatwa dalam mendorong produk-produk perbankan syariah dapat diterima dengan cepat oleh msyarakat khususnya umat Islam.

\section{Metode}

Paper ini merupakan penelitian kualitatif, dengan metode pendekatan filsafat hukum dan konsep ekonomi islam. Selain itu, paper ini juga didukung dengan fakta empiris tentang perkembangan ekonomi dan keuangan kontemporer. Pendekatan tersebut di arahkan untuk menganalisis perkembangan nalar hukum Islam (itjtihad dan fatwa) dan fenomena ekonomi dan keuangan kontemporer. Data yang diambil dalam paper ini adalah ayat, hadis dan fatwa Dewan Syariah Nasional-Majelis Ulama' Indonesia (DSN-MUI). Adapun data pendukung lainnya adalah buku dan jurnal-jurnal yang berkaitan dengan itjtihad dan fatwa.Data-data tersebut 
selanjutnya di sesuaikan dengan latar belakang sosiologis munculnya fatwa. Data-data itu kemudian ditelaah secara normatif dan konseptual.

\section{Pembahasan}

\subsection{Perkembangan Produk Teknologi Keuangan Syariah di Perbankan Syariah di Indonesia}

Perkembangan aset industri keuangan syariah bank di Indonesia mengalami tren peningkatan yang signifikan [12]. Menurut data Bank Indonesia 2018, kelembagaan bank yang exist dibidang keuangan dan bisnis syariah di Indonesia yaitu sebanyak 13 bank syariah, dengan 1.822 kantor, 348 kantor cabang yang melayani usaha syariah dan 168 bank BPRS dengan 458 kantor. Total aset keuangan syariah Indonesia mengalami peningkatan dari sebesar USD 47,6 miliar pada tahun 2016 menjadi USD 81,8 miliar pada tahun 2017 atau meningkat dari peringkat ke-9 menjadi peringkat ke-7 di dunia. Hingga 31 Mei 2018, total aset keuangan syariah terus meningkat mencapai USD 82,33 miliar. Pertumbuhan kegiatan ekonomi syariah di perbankan syariah menunjukkan trend yang terus berkembang.

Seiring dengan meningkatnya perkembangan dan pertumbuhan aset perbankan syariah, kebutuhan akan produkdan jasa juga semakin bertambah. Beragam inovasi produk diperbankan syariah bertujuan untuk memenuhi hasrat dan kebutuhan market share perbankan syariah yang terus meningkat. Pertumbuhan tersebut tidak lepas dari progresifitas produk-produk yang dikembangkan perbankan syariah.

Produk-produk perbankan syariah yang telah dilaksanakan sesuai prinsip syariah yaitu dibagi dalam empat produk, yaitu titipan atau simpanan, bagi hasil, jual beli dan jasa. produkproduk titipan atau simpanan yaitu melalui aqad wadi'ah dan mudharabah. Produk-produk bagi hasil melalui aqad bagi hasil, aqad kerjasama dibidang pertanian dan perkebunan. Produkproduk dengan skema aqad jual beli di perbankan syariah yaitu melalui aqad bai' almurabahah, bai' as-salam, bai' al-istishna', ijarah muntahia bit-tamlik (IMBT). Selanjutnya untuk produk-produk jasa perbankan syariah yatu melalui aqad wakalah, sharf, kafalah, hawalah, rahn dan qardh.

Membuat produk dan jasa baru dalam dunia perbankan syariah merupakan hal sangat mendesak. Inovasi-inovasi dibidang pengembangan produk disektor keuangan dan perbankan syariah merupakan hal yang paling pokok yang perlu didorong oleh pemerintah, untuk memenuhi perkembangan usaha masyarakat secara luas. Guna memastikan kehalalan produk dan jasa baru yang sesuai dengan syariah compliance, perbankan syariah dan seluruh lembaga keuangan syariah termasuk lembaga keuangan non-bank wajib mengikuti standar operasional prosedur yang telah diatur oleh Bank Indonesia. Lebaga keuangan syariah seperti Perbankan syariah pada tahap selanjutnya memberikan sistem perencanaan profil produk baru tersebut kepada Bank Indonesia. Penyampaian profil produk baru dapat disampaikan melalui salah satu dari dua mekanisme yaitu berupa sistem pengajuan permohonan persetujuan produk baru atau melalui laporan rencana pengeluaran produk baru [13].

Aqad-aqad dalam prinsip ekonomi syariah selanjutnya diwujudkan melalui kreatifitas produk-produk baru yang telah memperoleh izin Bank Indonesia. Produk-produk dan jasa tersebut selanjutnya dapat menguntungkan secara socio-profit dan menyentuh ekonomi masyarakat, serta menyesuaikan perkembangan masyarakat. Inovasi produk perbankan syariah terus berupaya memenuhi kebutuhan pasar dan sekaligus taat syariah. Produk-produk perbankan 
syariah yang kreatif dan taat prinsip tersebut mutlak dibutuhkan untuk membangkitkan semangat dan menumbuh-kembangkan perbankan syariah baik secara kualitas maupun kuantitas, atau pengembangan pada wilayah lokal, regional maupun daya saing secara internasional dengan antisipasi berbagai peluang dan tantangannya [13].

\subsection{Fatwa dan Kepastian Hukum Halal Produk di Bidang Keuangan Islam}

Kebutuhan masyarakat dan pasar terhadap perbankan syariah atas produk-produk perbankan terus meningkat. Kenyataan ini harus sejalan dengan pengembangan produk perbankan syariah yang sesuai dan patuh terhadap prinsip syariah. Legitimasi hukum kepatuhan para bankir atau pembuat produk dan jasa perbankan syariah terhadap prinsip syariah yaitu melalui fatwa Dewan Syariah Nasional Majelis Ulama' Indonesia (DSN-MUI)[14][15].

Sampai tahun 2018, fatwa yang berkaitan dengan keperbankanan, ekonomi dan keuangan syariah berjumlah 120 fatwa. Seluruh jumlah fatwa yang diterbitkan DSN-MUI dapat diklasifikasikan berdasarkan tahun sebagaimana tabel di bawah ini.

Tabel 1 Daftar Fatwa DSN-MUI

\begin{tabular}{ccc}
\hline No. & Tahun Penerbitan Fatwa DSN-MUI & Jumlah Fatwa DSN-MUI \\
\hline 1 & Tahun 2000 & 18 Fatwa \\
\hline 2 & Tahun 2001 & 3 Fatwa \\
\hline 3 & Tahun 2002 & 19 Fatwa \\
\hline 4 & Tahun 2004 & 4 Fatwa \\
\hline 5 & Tahun 2005 & 5 Fatwa \\
\hline 6 & Tahun 2006 & 5 Fatwa \\
\hline 7 & Tahun 2007 & 10 Fatwa \\
\hline 8 & Tahun 2008 & 9 Fatwa \\
\hline 9 & Tahun 2009 & 2 Fatwa \\
\hline 10 & Tahun 2010 & 3 Fatwa \\
\hline 11 & Tahun 2011 & 4 Fatwa \\
\hline 12 & Tahun 2012 & 5 Fatwa \\
\hline 13 & Tahun 2013 & 3 Fatwa \\
\hline 14 & Tahun 2014 & 5 Fatwa \\
\hline 15 & Tahun 2015 & 5 Fatwa \\
\hline 16 & Tahun 2016 & 8 Fatwa \\
\hline 17 & Tahun 2017 & 8 Fatwa \\
\hline 18 & Tahun 2018 & 4 Fatwa \\
\hline
\end{tabular}

Sumber: Fatwa DSN-MUI tahun 2018. https://dsnmui.or.id/produk/fatwa. Di akses Tanggal 9 Agustus 2018.

Berdasarkan tabel 1, mulai tahun 2000 hingga tahun 2018 terdapat 120 produk keuangan yang dikeluarkan oleh lembaga-lembaga keuangan syariah. Seratus dua puluh produk tersebut melahirkan 120 produk fatwa sebagai wujud "ijtihad" ulama' dalam merespons berbagai perkembangan produk keuangan islam. Pada tahun 2000 ada 18 fatwa, tahun 2001 ada 3 fatwa, tahun 2002 ada 19 fatwa, tahun 2004 terdapat 4 fatwa, tahun 2005 ada 5 fatwa, tahun 2006 ada 5 fatwa, tahun 2007 ada 10 fatwa, tahun 2008 ada 9 fatwa, tahun 2009 ada 2 fatwa, tahun 2010 ada 3 fatwa, tahun 2011 ada 4 fatwa, tahun 2012 ada 5 fatwa, tahun 2013 ada 3 fatwa, tahun 2014 ada 5 fatwa, tahun 2015 ada 5 fatwa, tahun 2016 ada 8 fatwa, tahun 2017 ada 8 fatwa dan tahun 2018 ada 4 fatwa DSN-MUI. 
Fatwa sebagai wujud respon terhadap perkembangan produk syariah merupakan fungsi utama bagi masyarakat. Fatwa hadir tidak hanya untuk meligitimasi kepastian hukum bermuamalah di lembaga-lembaga keuangan Islam, namun yang lebih penting adalah posisi fatwa telah menjadi barometer dan naungan bagi kesesuaian produk terhadap prinsip-prinsip syariah [16]. Fatwa DSN-MUI tahun 2017 dan tahun 2018 merupakan contoh nyata respons ulama' dalam mengatasi kegelisahan masyarakat terhadap status hukum uang elektronik, transaksi online dan perkembangan teknologi keuangan. Maraknya perkembangan teknologi keuangan termasuk di lembaga keuangan syariah merupakan dampak dari kuatnya arus ekonomi digital dan digitalisasi ekonomi. Perkembangan ekonomi digital tersebut selanjutnya membawa seluruh transaksi saat ini bersifat praktis, simple, efektif, dan paperless. Empat karakter inilah yang kemudian melahirkan konsep baru di bidang manajemen keuangan modern yang disebut dengan teknologi keuangan atau financial technology atau dikenal dengan fintech. Fintech sebagaimana fenomena baru juga tidak luput dari perhatian ulama, sehingga pada tahun 2017 dan tahun 2018 DSN-MUI mengeluarkan fatwa tentang status hukum uang elektronik dan status hukum transaksi keuangan dan bisnis melalui fintech atau teknologi informasi sebagaimana fatwa Dewan Syariah Nasional Majelis Ulama IndonesiaNomor 116/DSN-Mui/IX/20I7 tentang Uang Elektronik Syariah, dan fatwa Dewan Syariah Nasional Majelis Ulama Indonesia Nomor 117/DSN-MUI/II/2018 tentang Layanan Pembiayaan Berbasis Teknologi Informasi Berdasarkan Prinsip Syariah.

Mekanisme pengembangan produk-produk keuangan tersebut melalui serangkaian proses cek dan filterisasi kehalalan prosedur dan aqad-nya melalaui itjtihad yang dilakukan DSN-MUI. Produk baru keuangan syariah tidak dapat diterima begitu saja. Produk keuangan tidak dapat disalurkan kepada masyarakat, melainkan harus diperiksa terlebih dahulu mekanisme sesuai peraturan Bank Indonesia dan DSN-MUI. Perijinan produk bertujaun untuk mendeteksi potensi gharar, riba, dan potensi transaksi haram didalamnya [17].

\subsection{Signifikansi Ijtihad dalam Pengembangan Produk Perbankan Syariah}

Loncatan kemajuan sains dan teknologi modern di era globalisasi serta perkembangan ekonomi digital telah menimbulkan dampak besar terhadap kehidupan umat manusia. Salah satu dampak tersebut yaitu seperti tata cara bisnis secara online, berkembangnya platform teknologi keuangan, perkembangan sistem pembayaran dan pinjaman dalam jual beli online melalui kartu kredit, internet banking, bisnis ekspor atau impor melalui Latter of Credit, sistem instrumen pengendalian moneter, zakat dan waqf saham, dan lain-lain.

Bagi umat Islam, digitalisasi bisnis dan teknologi keuangan, memerlukan legitimaasi hukum. Dalam ilmu ushul fiqh, sumber hukum dalam ekonomi yaitu Alquran dan Hadits. Seluruh masalah hukum dalam muamalah harus tunduk dan patuh terhadap aturan dalam Alquran dan Hadits. Jika didalam Alquran dan Hadits tidak ada dalil yang jelas, maka sumber selanjutnya adalah melalui ijma' para ulama. Jika ijma' juga tidak memberikan jawaban yang jelas, maka tahap selanjutnya adalah melalui qiyas atau analogi hukum, istishab, istihsan termasuk melalui fatwa. Potensi mengerahkan seluruh pemikiran, daya, dan upaya mulai ijma', qiyas dan seterusnya merupakan gerakan ijtihad [18]. Ijtihad merupakan sebuah sikap dengan cara berusaha sungguh-sungguh untuk merumuskan suatu hukum yang tidak permasalahan dan sumbernya belum pernah dikaji dalam sumber utama hukum islam yaitu Alquran, dan Hadits dan dalam wilayah furu. Ijtihad dalam lapangan ushul figh senantiasa memposisikan akal sehat dan jernih dalam memutuskan sebuah perkara baru tersebut [19]. 
Penerapan ijtihad dalam pengembangan teknologi keuangan islam memiliki ruang lingkup yang lebih luas dibanding ibadah. Ajaran islam tentang muamalah umumnya bersifat global, karena itu ruang ijtihad jauh lebih luas. Ekonomi islam yang menjadi salah satu bidang muamalah berbeda dengan ibadah seperti shalat, puasa, dan haji (ibadah mahdhah). Ibadahibaah seperti shalat, puasa, haji lebih bersifat ta 'abbudiyah, sehingga sedikit sekali ruang untuk melakukan kreativitas dan inovasi hukum didalamnya. Ruang ijtihad dalam bidang ibadah sangat sempit. Berbeda sekali dengan wilayah ekonomi Islam atau iqtishadiyah yang cukup terbuka dalam mengembangakan daya kreativitas dan inovasi dalam membangun dan mengembangkan produk-produk ekonomi islam. Oleh karena itu prinsip ijtihad dalam bidang muamalah menjadi acuan dan patokan penting. Apalagi bila menyangkut kebijakan-kebijakan ekonomi yang bersifat manthiqah al-firagh al-tasyri'y (area yang kosong dari tasyri'/hukum). Hal ini disebabkan sedikitnya nash-nash yang menyinggung masalah yang terkait dengan kebijakan-kebijakan ekonomi. Hal ini pula yang selanjutnya membuka peluang besar untuk mengembangkan itjtihad dibidang ekonomi salah satunya melalui fatwa.

Nilai-nilai kemaslahatan dalam bidang muamalah dapat ditemukan oleh akal/pemikiran manusia melalui ijtihad. Salah satu wujud ijtihad yang dilakukan DSN-MUI yaitu melalui fatwa. Fatwa sebagai salah satu isntrumen ijtihad menjadi sangat vital dalam pengembangan ekonomi islam dan siyasah iqtishadiyah (kebijakan ekonomi) di Indonesia. Fatwa merupakan kebijakan syariah (siyasah syar `iyyah) dalam merespon dinamika sosial, politik, dan ekonomi. Kehadiran fatwa bertujuan untuk menemukan kemaslahatan yang bersifat umum, yaitu kemaslahatan yang dibingkai secara syar'i, bukan semata-mata profit oriented dan material rentability sebagaimana dalam produk ekonomi konvensional. Dengan demikian, pengembangan ekonomi islam dalam menghadapi perubahan dan kemajuan sains teknologi yang pesat berdasarkan fatwa dan peran spirit ijtihad merupakan sebuah keniscayaan.

Eksistensi perbankan syariah tidak luput dari pengembangan produk-produk dan jasa keuangan yang inovatif. Inovasi produk di perbankan syariah menjadi strategi prioritas bagi bank-bank syariah di tengah pasar yang kompetitif. Pengembangan produk lembaga keuangan syariah bank saat ini cendrung mengalami stagnasi, yaitu masih terbatas pada tabungan, deposito, giro, akad-akad pembiayaan bagi hasil, dan kerjasama [20]. Perbankan syariah sudah saatnya mengembangkan produk-produk yang variatif, sehingga menambah daya tarik masyarakat. Mendorang kreativitas dan inovasi sebuah produk baru yang berbasis syariah, tidak cukup sekedar dengan meniru atau merujuk produk-produk yang sudah dipraktikkan dalam kinerja lembaga keuangan syariah lain. Kreativitas dan inovasi sebuah produk lembaga keuangan syariah disketor perbankan dapat dilakukan dengan menggali terlebih dahulu dan mengembangkan landasan-landasan hukum muamalah (Al-Quran dan Hadits) secara kreatif konsep-konsep dasar dalam fikih muamalah yang menbahas isu-isu terkini dan aktual dengan menggunakan ilmu ushuliyah dibidang keuangan syariah, dan maqashid syariah aliqtishadiyyah. Metode ijtihad dengan menyampaikan dan menguraikan terlebih dahulu pendapat ulama yang paling kuat serta metode ijtihad dengan menetapkan hasil keputusan ulama terdahulu dapat dijadikan terobosan dalam menggarap proyek baru atau profil produk dan jasa bagi sebuah lembaga keuangan syariah termasuk di perbankan syariah.

Selain melambatnya progres pengembangan produk, perkembangan perbankan syariah juga sebabkan stagnasi regulasi dan norma dalam wilayah hukum. Perkembangan norma hukum dalam berbagai studi, selalu berada dibelakang perkembangan ekonomi dan sosial. Posisi hukum atau aturan atau undang-undang berada di belakang perkembangan ekonomi dan sosial. Pandangan ini termaktub di dalam sebuah moto hukum yaitu het recht hink achter de feiten aan yang artinya hukum/undang-undang berjalan dibelakang kejadian/peristiwa yang muncul di 
masyaarakat. Undang-undang senantiasa terseok-seok/tertatih-tatih berupaya mengejar peristiwa/fakta yang seyogyanya diaturnya.

Meski hukum atau undang-undang selalu tertatih-tatih di belakang prilaku ekonomi, posisi hukum tetap mejadi parameter dan rujukan utama ketika terjadi konflik termasuk dalam masalah ekonomi. Eksistensi fatwa misalnya, dapat menjadi instrumen kepastian hukum dalam produk halal keuangan di lembaga keuangan Islam. Hal inilah yang dapat dilakukan untuk tetap menjadi pengawal perkembangan ekonomi yang sesuai prinsip syariah. Oleh sebab itu, dalam konstruksi hukum di Indonesia, fatwa senantiasa mengikuti perubahan zaman. Jika ada pegadaian syariah, maka muncul fatwa DSN-MUI tentang pegadaian syariah. Demikian halnya dengan munculnya fenomena fintech maka DSN-MUI berupaya memberikan petuahnya melalui fatwa DSN-MUI tentang fintech syariah. Semangat inilah yang akhirnya DSN-MUI mampu melahirkan 120 produk fatwa sebagai respon terhadap perkembangan ekonomi dan keuangan termasuk fatwa tentang pengembangan teknologi keuangan syariah, sebagai wujud respons perkembangan zaman yang terus berubah [21]. Peran fatwa ini selaras dengan prinsip hukum yaitu perubahan hukum bergantung pada perubahan waktu, tempat, dan keadaan.

Namun dalam pekembangan ekonomi syariah, urgensi fatwa DSN-MUI dalam mengawal pengembangan produk Islamic fintech tidak cukup berhenti hanya pada justifikasi produk dan kehalalan prosedur dalam transaksi. Akan tetapi yang paling penting adalah fatwa DSN-MUI dapat berperan pada lapisan aksiologis dalam mengawal kebermanfaatan produk keuangan syariah yang telah difatwakan [22]. Hingga saaat ini, produk-produk keuangan syariah di lembaga-lembaga keuangan islam masih belum banyak berkontribusi dan mampu bersaing dalam mendongkrak pertumbuhan ekonomi secara makro, inflasi, fiskal, CSR, dan belum mampu menekan angka kemiskinan [23]. Seperti masalah CSR, DSN-MUI dapat memformulasi Fatwa CSR sebagai sumber hukum yang dapat memberikan dorongan moril kepada pelaku usaha.

Fatwa sebagai pengawal tegaknya prinsip syariah dalam lapangan ekonomi seyogyanya dapat dan mampu menjangkau goal akhir dari sebuah transaksi. Fatwa saat ini masih terkesan hanya bermanfaat untuk meloloskan dalam ranah epistimologis dari produk dan jasa keuangan melalui norma atau aturan yang sesuai fikih [24]. Namun, fungsi fatwa sebagai pengawal manfaat dan kemaslahatan pada ranah aksiologis dari sebuah transaksi, posisi fatwa masih belum memiliki kejelasan fungsi. Oleh sebab itu, jika fatwa dianggap sebagai pengawal tegaknya prinsip syariah dalam pengembangan teknologi keuangan Islam, maka fatwa dalam konstruksi hukum progresif, fatwa harus selangkah lebih maju yaitu mampu mengawal kemaslahatan dan pemerataan keuntungan dari produk dan jasa keuangan bagi masyarakat secara luas.

\section{Kesimpulan}

Berdasarkan analisis, paper ini menyimpulkan bahwa pertumbuhan dan perkembangan aset lembaga keuangan syariah seperti perbankan syariah menunjukkan tren yang terus meningkat. Peningkatan tren perkembangan keuangan dan ekonomi di bidang perbankan syariah ternyata linier dengan tumbuhnya semangat progresifitas itjtihad DSN-MUI yang mengeluarkan 120 fatwa tentang keuangan Islam sejak tahun 2000 hingga tahun 2018. Kedudukan itjtihad progresif melalui fatwa dalam pengembangan produk perbankan syariah merupakan epistimologi hukum dalam mengikuti perkembangan ekonomi digital dibidang perbankan syariah. Namun, perkembangan dan progresivitas fatwa belum mampu 
meningkatkan pertumbuhan aset perbankan syariah. Fatwa masih berfungsi sebagai legitimasi fikih di perbankan syariah an sich. Fatwa belum berkontribusi dalam mendukung sektor riil, kebijakan moneter, menekan angka kemiskinan, dan meningkatkan income masyarakat.

\section{References}

[1] Michael G. Plummer, Peter A. Petri and Fan Zhai, (2014) Assesing the Impact of ASEAN Economic Integration on Labour Markets. ILO Asia-Pacific Working Paper Series. ILO Regional Office for Asia and the Pacific. Bangkok: ILO, 2014. xi. 54. ISSN: 2227-4405.

[2] Stanislaus Risadi Apresian, "Arus Bebas Tenaga Kerja dalam Era Masyarakat Ekonomi ASEAN: Ancaman bagi Indonesia?," Indonesian Perspective, Vol. 1, No. 2 (Juli-Desember 2016), p. 15-29.

[3] Halim Alamsyah, "Perkembangan dan Prospek Perbankan Syariah Indonesia: Tantangan Dalam Menyongsong MEA 2015,” Makalah Disampaikan dalam Ceramah Ilmiah Ikatan Ahli Ekonomi Islam (IAEI), Milad ke-8 IAEI, 13 April 2012.

[4] Filippo di Mauro, at al., "Islamic Finance in Europe," Occasional Paper Series, ISSN 1725-6534. No. 146/June 2013, European Central Bank, Germany 2013. p. 32-34.

[5] Agustianto, "Inovasi Produk Perbankan Syariah" dalam https://www.iqtishadconsulting.com/content/read/ blog/inovasi-produk-perbankan-syariah-bagian1. Diakses Tanggal 15 Agustus 2018.

[6] David Bassens, at al., "Setting Shari'a Standards: On the Role, Power And Spatialities Of Interlocking Shari'a Boards in Islamic Financial Services," Geoforum 42 (2011), 94-103.

[7] Ulrich Derigs, \&Shehab Marzban, "New Strategies And A New Paradigm For Shariah-Compliant Portfolio Optimization," Journal of Banking \& Finance 33 (2009) 1166-1176.

[8] Umair Riaz, at al.,"Perceptions On The Accessibility Of Islamic Banking in the UK-Challenges, Opportunities and Divergence in Opinion," Accounting Forum (2017).

[9] Nurhafiza Abdul Kader Malim, \& M.K. Normalini, "Factors Influencing the Margins of Islamic Banks," Global Business Review 19 (4) 1-11, 2018.

[10] Imam Buchari at al., "Awareness and attitudes of employees towards islamic banking products in Bahrain," 3rd Economics \& Finance Conference, Rome, Italy, April 14-17, 2015 and 4th Economics \& Finance Conference, London, UK, August 25-28, 2015.

[11] Fredj Jawadia, at al.,"Modelling the Effect of the Geographical Environment on Islamic Banking Performance: A Panel Quantile Regression Analysis,"Economic Modelling 67 (2017) 300-306.

[12] Aisalkyn Botoeva, "Islam and the Spirits of Capitalism: Competing Articulations of the Islamic Economy," Politics \& Society, 2018, Vol. 46(2) 235-264.

[13] Fahrur Ulum, "Inovasi Produk Perbankan Syariah di Indonesia," Al-Qānūn, Volume 17, Nomor 1, Juni 2014. P. 1-4.

[14] Melissa Crouch (2013)."Shifting Conceptions of State Regulation of Religion: the Indonesian Draft Law on Inter-religious Harmony, Global Change, Peace \& Security: Formerly Pacifica Review: Peace, Security \& Global Change, 25:3, 265-282.

[15] Tim Lindsey (2012)."Monopolising Islam: The Indonesian Ulama Council and State Regulation of the 'Islamic Economy,"Bulletin of Indonesian Economic Studies, 48:2, 253-274.

[16] Patrick Imam,Kangni Kpodar, "Islamic banking: Good for growth?," Economic Modelling 59 (2016) 387-401.

[17] Kabir Hassan, \& M., Aliyu, Sirajo, “A Contemporary Survey of Islamic Banking Literature. Journal of Financial Stability. Mohamad Abdun Nasir (2014)."The 'Ulamā', Fatāwā and Challenges to Democracy in Contemporary Indonesia, Islam and Christian-Muslim Relations, 25:4, 489-505.

[18] Han El-Fawal, "Court Systems: Sharii'ahLawandCourts Albany College of Pharmacy and Health Sciences," Albany, NY, USA r 2016. Encyclopedia of Forensic and Legal Medicine, Volume 1.

[19] Syamsul Hadi (1989).“"The Indonesian council of ulama, Indonesia Circle. School of Oriental \& African Studies."Newsletter, 18:50, 31-41.

[20] Keria Kontot, at al., "Determining Factors of Customers' Preferences: A Case of Deposit Products 
in Islamic Banking," 6th International Research Symposium in Service Management, IRSSM-6 2015, 11-15 August 2015, UiTM Sarawak, Kuching, Malaysia, Procedia - Social and Behavioral Sciences 224 (2016) 167 - 175. M. Samers, “Islamic Housing Finance,”University of Kentucky, Lexington, KY, USA.

[21] Tim Lindsey (2012).“Monopolising Islam: The Indonesian Ulama Council and State Regulation of the 'Islamic Economy', Bulletin of Indonesian Economic Studies, 48:2, 253-274.

[22] Mohamad Abdun Nasir (2014) The "Ulama', Fatawa and Challenges to Democracy in Contemporary Indonesia," Islam and Christian-Muslim Relations, 25:4, 489-505.

[23] Lena Rethel (2017). "Economic Governance Beyond State and Market: Islamic Capital Markets in Southeast Asia,"Journal of Contemporary Asia.

[24] Julian Millie and Linda Hindasah,Regional Aspects of the Indonesian Ulama Council's Ideological Turn, The Asia Pacific Journal of Anthropology, 2015 Vol. 16, No. 3, 260-281. 